\title{
DNA Topoisomerase 3-Alpha
}

National Cancer Institute

\section{Source}

National Cancer Institute. DNA Topoisomerase 3-Alpha. NCI Thesaurus. Code C20109.

DNA topoisomerase 3-alpha (1001 aa, 112 kDa) is encoded by the human TOP3A gene.

This protein is involved in the relaxation of supercoiled DNA. 